\title{
Pengaruh Formulasi Kadar Protein dan Kalsium pada MP-ASI Kacang Tunggak dan Beras Merah terhadap Uji Organoleptik pada Ibu Bayi dan Uji Daya Terima pada Bayi
}

\author{
Qorry Aina $^{1 *}$, Bayu Irianti ${ }^{2}$ \\ ${ }^{1}$ Prodi S1 Ilmu Gizi STIKES Surabaya \\ ${ }^{2}$ Prodi D3 Kebidanan Poltekkes Kemenkes Tasikmalaya \\ *qorry.aina@stikessurabaya.ac.id
}

\begin{abstract}
Background: The prevalence of stunting toddlers in Indonesia is still high. The causes of stunting include the low nutritional value of food consumed by infants. Foods that are rich in nutrients include cowpea and brown rice. Objective: to determine the acceptability and protein and calcium content of porridge with the addition of cowpea and rice through organoleptic testing. Method: this type of research is quasi-experimental. Data collection through organoleptic test on the baby's mother and acceptance test in baby. Addition of cowpea and brown rice are X1 cowpea $100 \%$ brown rice $50 \%$ and X2 cowpea $50 \%$ and brown rice $100 \%$ Analysis of organoleptic test data on porridge using Mann Whitney. Results: Statistical test results showed that the use of cowpea and brown rice affected the color of the porridge ( $p=$ $0.00)$ and the taste of the porridge $(p=0.04)$. The use of cowpea and brown rice had no effect on the aroma of porridge $(p=0.06)$, texture $(p=0.93)$ and preference level $(p=0.94)$. Results acceptance porridge with formula X2 more acceptable than X1 because have a higher average and less limp. The highest content of pro-tein and calcium in porridge at X1 is $3.29 \%$ and $70.40 \mathrm{mg} / \mathrm{kg}$. Conclusion: the use of cowpea and brown rice in MP-ASI baby porridge affected the organoleptic test results in the color category, and the taste of the porridge.
\end{abstract}

Keywords: cowpea, brown rice, weaning food

\section{PENDAHULUAN}

Masalah gizi masih menjadi polemik yang memengaruhi derajat kesehatan di Indonesia. Prevalensi balita kurang gizi di Indonesia pada tahun 2013 sebesar 14.9\% dan $3.8 \%$ diantaranya berstatus gizi buruk. (Riskesdas, 2013) status gizi menjadi penyumbang kejadian balita pendek (stunting) dan balita kurus (wasting) di Indonesia. Angka kejadian stunting di Indonesia termasuk kategori tinggi yaitu memiliki rentang 22.5\%-58.4\%. Prevalensi wasting secara nasional mencapai $13.3 \%$ yang menandakan status gizi balita di Indonesia terbilang rendah. Di jawatimur tercatat 800 ribu dari total 4 juta balita mengalami gizi buruk (Umar, 2014).

Data riset kesehatan dasar (Riskesdas) tahun 2013 menunjukkan bahwa salah satu penyebab terjadinya kualitas gizi yang buruk adalah rendahnya nilai konsumsi makanan dari penduduk Indonesia, yaitu di bawah 70\% (kebutuhan minimum 
kecukupan gizi). Rendahnya niai konsumsi makanan pada orang dewasa memengaruhi pola pemberian makanan pada balita, sehingga tidak terpenuhinya kebutuhan zat gizi secara adekuat.

Salah satu masalah gizi yang sering terjadi pada anak balita adalah kekurangan energi protein (KEP) yang dapat menyebabkan penurunan imunitas tubuh dan menyebabkan anak rentan terkena penyakit. Dampak jangka Panjang lain dari KEP terhambatnya pertumbuhan dan perkembangan anak, serta produktivitas dan daya saing yang rendah. Permasalahan gizi yang tidak ditangani dengan baik akan menjadikan generasi Indonesia memiliki keterlambatan dalam daya saing dan mengalami kemunduran produktivitas dalam kurun 15 tahun ke depan.

Makanan pendamping ASI (MP-ASI) memegang peranan penting dalam pemenuhan kebutuhan zat gizi pada bayi dan balita setelah pemberian ASI ekslusif. Penambahan zat mikro menjadi salah satu cara meningkatkn kualitas gizi MP-ASI. Pemberian formula modifikasi MP-ASI yang tepat berhubungan dengan peningkatan status gizi balita (Widodo, 2015). Penelitian mengenai MP-ASI menjadi topik yang menarik untuk dilakukan. Salah satu penelitian yang dilkukan oleh Bernard (2006) menyimpulkan bahwa formula MPASI berbahan dasar jagung, pepaya, ka- cang merah dan ikan tuna dapat meningkatkan status gizi dan mampu mencegah kekurangan energi dan protein.

Bahan makanan sumber karbohidrat pada MP-ASI dapat berupa beras putih, beras merah, jagung, kentang, tepung terigu dan lain lain. Penggunaan beras merah sebagai bahan dasar MP-ASI lebih banyak dilakukan oleh pihak industri. Hal tersebut dilakukan karena beras merah memiliki rasa yang lebih manis dan memiliki manfaat kesehatan lebih banyak. Beras merah mengandung nutrisi lebih banyak daripada beras putih diantaranya protein, lemak, folat, vitamin E dan lain lain (Folley,2001).

Indonesia merupakan negara penghasil kacang tunggak yang cukup besar. Kandungan makro dan mikro nutrient yang cukup tinggi pada kacang tunggak menjadikannya bahan pilihan untuk modifikasi pangan. Selain itu, kacang tunggak mudah didapatkan di Indonesia dengan harga yang cukup dijangkau. Pengolahan kacang tunggak di Indonesia belum optimal dan dikelola dengan metode tradisional dan sederhana. Kacang tunggak saat ini dimanfaatkan dalam industri makanan yang hanya terbatas pada kue dan industri pakan ternak (Rukmana dan Yuniarsih, 2001).

Kandungan protein kacang tunggak berkisar antara $18,3-25,53 \%$, energi 342 (kkal), lemak 1,4 g, karbohidrat 61,6 g, kalsium $77 \mathrm{mg}$, dan fosfor $449 \mathrm{mg}$ (Rosida, 
2013). Kandungan gizi pada kacang tunggak dapat dijadikan pertimbangan modifikasi makanan serta menjadi alternatif penyelesaian masalah kurang gizi pada balita dengan menjadikannya campuran pada MP-ASI. Campuran MP-ASI kacang tunggak diberikan pada bayi usia 7-12 bulan dengan mencampurkannya dengan beras merah.

\section{METODE}

Jenis penelitian ini adalah ekperimental yang dibagi menjadi beberapa tahap yaitu formulasi MP-ASI berupa bubur berbahan dasar kacang tunggak dan beras merah, uji organoleptik pada ibu bayo dan bayi, dan uji kandungan protein dan kalsium bubur. Penelitian ini dilakukan di laboratorium kulinari di STIKes Surabaya untuk pembuatan formulasi bayi, posyandu di wilayah kerja Puskesmas Mulyorejo untuk uji organoleptik bubur, serta Badan Penelitian dan Pengembangan Industri Surabaya untuk pengujian kandungan gizi bubur.

Bahan utama yang digunakan dalam pembuatan bubur yaitu beras merah, keju, mentega yang dibeli di supermarket "Lottemart", kacang tunggak yang dibeli di pasar local di Surabaya. Alat yang digunakan dalam pembuatan bubur yaitu panci, kukusan, kompor, tabung LPG, regulator, sendok, spatula kayu, mangkok, dan parutan keju.

\section{Formulasi bubur bayi}

Pembuatan formula bubur bayi mengacu pada persyaratan MP-ASI. Kriteria makanan pendamping ASI diantaranya berada dalam derajat kematangan yang sesuai, bebas dari pencemaran pada saat proses penyimpanan hingga penyuapan pada bayi, tidak mengalami perubahan fisik, kimia yang dikehendaki, bebas dari mikroorganisme dan parasite yang berbahaya, mengandung kalori dan nutrisi yang cukup serta mudah dicerna. Formula bubur ditetapkan berdasarkan penelitian pendahuluan pada panelis terbatas sehingga menghasilkan 2 formula yang akan diujicobakan pada panelis tidak terlatih. Formula tersebut yaitu X1 kacang tunggak $100 \%$ beras merah 50\% dan X2 kacang tunggak $50 \%$ dan beras merah $100 \%$. Formula bubur bayi pada penelitian ini dapat dilihat pada Tabel 1.

Tabel 1. Formula Bubur Bayi Berbahan Dasar Kacang Tunggak dan Beras Merah

\begin{tabular}{lcc}
\hline \multirow{2}{*}{ Bahan } & \multicolumn{2}{c}{ Formula } \\
\cline { 2 - 3 } & X1 & X2 \\
\hline Beras merah (gram) & 25 & 20 \\
\hline Beras putih (gram) & 50 & 50 \\
\hline Kacang tunggak (gram) & 50 & 30 \\
\hline Keju (gram) & 10 & 10 \\
\hline Mentega (gram) & 10 & 10 \\
\hline Air (ml) & 650 & 650 \\
\hline
\end{tabular}

Pembuatan bubur bayi dilakukan dengan cara penimbangan semua bahan yang digunakan, perendaman beras selama 60 menit, kacang tunggak selama 180 menit. Kedua bahan direbus dan ditambahkan air. Adonan bubur dihaluskan menggunakan blender lalu disaring. 


\section{Uji organoleptik bubur oleh ibu bayi}

Formula bubur bayi diujikan kepada $30 \mathrm{ibu}$ bayi dan bayi di posyandu wilayah kerja Puskemas Mulyorejo dengan kriteria inklusi tidak memiliki riwayat penyakit yang mengganggu panca indera. Uji organoleptik meliputi warna, aroma, rasa, tekstur, dan tingkat kesukaan. Penilaian warna terdiri dari $1=$ merah muda, $2=$ merah, $3=$ merah tua, $4=$ merah kecoklatan . Penilaian aroma $1=$ Tidak beraroma kacang tunggak dan beras merah, 2= Agak beraroma kacang tunggak dan beras merah, $3=$ Cukup beraroma kacang tunggak dan beras merah, 4 = Sangat beraroma kacang tunggak dan beras merah. Penilaian rasa terdiri dari $1=$ Tidak berasa kacang tunggak dan beras merah, 2= Agak berasa kacang tunggak dan beras merah, $3=$ Cukup berasa kacang tunggak dan beras merah, 4= Sangat berasa kacang tunggak dan beras merah. Penilaian tekstur terdiri dari $1=$ Tidak kental, $2=$ agak kental, $3=$ cukup kental, $4=$ kental. Penilaian tingkat kesukaan $1=$ tidak suka, $2=$ agak suka, $3=$ cukup suka, $4=$ suka.

Uji penerimaan bubur oleh bayi

Formula bubur diuji daya terima ke bayi. Kriteria panelis yaitu bayi berusia 612 bulan, dalam keadaan sehat dan dengan persetujuan ibunya. Bayi tidak dapat menjadi panelis jika bayi mengalami gangguan kesehatan seperti sakit gigi, sariawan dan gangguan pencernaan. Pengujian daya Jurnal Gizi Vol 9 No 1 Tahun 2020 terima dilakukan saat kegiatan posyandu serentak. Sebelum pengujian dimulai, ibu bayi atau pengasuh diberi penjelasan tentang pengisian kuesioner daya terima bubur oleh bayi. Menurut Guinard (2001) penilaian dilakukan dengan melihat raut muka (tingkat kesukaan berdasarkan raut muka) dan ada atau tidaknya lepehan dari 2 suapan bubur. Berikut ini skala raut muka yang digunakan untuk penilaian dapat dilihat pada Gambar 1

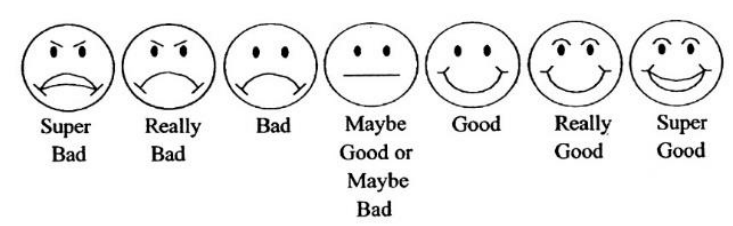

Gambar 1. Skala Hedonik Raut Muka

Keterangan:

Superbad $=1$

Reallybad $=2$

$\mathrm{Bad}=3$

Maybe good or maybe bad $=4$

Good $=5$

Really good $=6$

Super good $=7$

\section{Uji kandungan gizi bubur}

Bubur bayi MP-ASI diuji kandungan protein dengan metode Kjeldahl dan kandungan kalsium dengan metode Ca (AAS).

\section{Analisis data}

Data dianalisis menggunakan aplikasi SPSS 16 dengan uji Mann-Whitney Test.

\section{HASIL DAN PEMBAHASAN}


Rata-rata hasil uji organoleptik oleh ibu bayi dapat dilihat pada Tabel 2 .

Tabel 2. Rata-rata hasil Uji Organoleptik oleh Ibu Bayi

\begin{tabular}{lc}
\hline Formula & Mean \pm SD \\
\hline Warna & \\
\hline X1 & 2,33 \\
\hline X2 & 3,67 \\
\hline Aroma & \\
\hline X1 & 3,00 \\
\hline X2 & 2,90 \\
\hline Rasa & \\
\hline X1 & 2,13 \\
\hline X2 & 2,70 \\
\hline Tekstur & 3,20 \\
\hline X1 & 3,20 \\
\hline X2 & 2,9 \\
\hline Tingkat Kesukaan \\
\hline X1 & 2,8 \\
\hline X2
\end{tabular}

Tabel 2 menunjukkan bahwa nilai rata-rata penilaian warna tertinggi pada $\mathrm{X} 2$ dengan kriteria warna merah kecoklatan. Nilai rata-rata penilaian aroma tertinggi pada X1 dengan kriteria cukup beraroma kacang tunggak dan beras merah. Nilai rata-rata penilaian rasa tertinggi pada $\mathrm{X} 2$ dengan kriteria cukup berasa kacang tunggak dan beras merah. Penilaian tekstur dari dua sample memiliki nilai rata-rata yang sama dengan kriteria cukup kental. Nilai rata-rata tingkat kesukaan pada sampel X1 dengan kriteria cukup suka.

Hasil uji statistik menunjukkan bahwa penggunaan kacang tunggak dan beras merah berpengaruh pada warna bubur $(\mathrm{p}=0,00)$ dan rasa bubur $(\mathrm{p}=0,04)$. Penggunaan kacang tunggak dan beras merah tidak berpengaruh pada aroma bubur $(\mathrm{p}=0,06)$, tekstur $(\mathrm{p}=0,93)$ dan tingkat kesukaan $(\mathrm{p}=0,94)$.
Uji penerimaan bubur oleh panelis bayi

Hasil uji penerimaan bubur oleh bayi dapat dilihat pada Tabel 3 .

Tabel 3. Hasil uji penerimaan bubur oleh bayi

\begin{tabular}{lll}
\hline Skala raut muka & \multicolumn{2}{l}{ Jumlah panelis } \\
\cline { 2 - 3 } & X1 & X2 \\
\hline 1 & 2 & 2 \\
\hline 2 & 2 & 2 \\
\hline 3 & 8 & 7 \\
\hline 4 & 5 & 3 \\
\hline 5 & 9 & 13 \\
\hline 6 & 3 & 2 \\
\hline 7 & 1 & 1 \\
\hline Nilai Rata-rata & 4 & 4,1 \\
\hline Lepehan & \multicolumn{2}{l}{ Jumlah panelis } \\
\cline { 2 - 3 } & X1 & X2 \\
\hline Ada & 9 & 8 \\
\hline Tidak ada & 21 & 22 \\
\hline
\end{tabular}

Tabel 3 menunjukkan bahwa nilai rata-rata tertinggi dari skala raut muka yaitu X2. Tabel 3 menunjukkan jumlah balita yang lebih sedikit mengeluarkan lepehan adalah X2.

Uji kandungan gizi bubur

Hasil uji kandungan gizi bubur dapat dilihat pada Tabel 4.

Tabel 4. Hasil Uji Kandungan Bubur

\begin{tabular}{lll}
\hline Formula & XI & X2 \\
\hline Protein $(\%)$ & 3,29 & 3,28 \\
\hline Kalsium mg/kg & 70,40 & 52,94 \\
\hline
\end{tabular}

Tabel 4 menujukkan bahwa kandungan protein pada kedua sampel terdapat selisih 0,01 dan kandungan kalsium terdapat selisih 17,46 dengan kandungan tertinggi pada formula $\mathrm{X} 1$.

Warna yang dihasilkan dalam pembuatan bubur kacang tunggak dan beras merah yaitu warna merah kecoklatan. 
Warna merah kecoklatan disebabkan karena penggunaan beras merah. Perbedaan warna pada X1 dan X2 disebabkan karena Menurut Pengkumsri (2015) Beras merah kaya akan pigmen antosianin, fitokimia, protein, dan vitamin. Zat warna yang terdapat pada beras merah merupakan senyawa alami proantocyanin yang dapat mencegah tekanan darah tinggi, diabetes, menurunkan risiko penyakit kardiovaskular dan kanker. Hal ini sejalan dengan penelitian ini sejalan dengan penelitian Ilowefah (2014) yang menyimpulkan bahwa substitusi beras merah pada bolu kukus dapat meningkatkan daya terima karena warnanya semakin pekat.

Aroma bubur yang dihasilkan dalam pembuatan bubur MP-ASI kacang tunggak dan beras merah yaitu aroma khas kacang tunggak dan beras merah. Beras merah memiliki aroma khas dan langu (Febriana, 2014). Rasa langu pada beras merah berkurang karena adanya proses perendaman dan perebusan bubur. Semakin banyak penggunaan beras merah maka aroma langu pada makanan semakin kuat. Hal ini sejalan dengan penelitian yang dilakukan oleh Puspita (2016) yang menyimpulkan semakin banyak pencampuran beras merah pada bolu kukus maka aroma langu semakin meningkat.

Rasa bubur bayi MP-ASI kacang tunggak dan beras merah menghasilkan rasa khas kacang tunggak dan beras merah.
Bubur bayi cenderung menghasilkan rasa gurih karena menggunakan bahan dasar mentega. Mentega mempunyai kandungan lemak dan protein yang menyebabkan rasa gurih pada bubur yang dihasilkan. Demikian juga kandungan protein dan lemak yang terkandung dalam mentega juga berpengaruh pada panelis terhadap rasa bubur (Sarofa et al. 2013). Hal ini sejalan dengan penelitian oleh Amalia (2014) semakin banyak tepung beras merah yang ditambahkan menyebabkan rasa khas tepung pada cookies semakin pekat.

Tekstur bubur MP-ASI yang dihasilkan sudah sesuai dengan standar SNI MP-ASI berupa bubur yaitu kental. Tekstur bersifat kompleks dan terkait dengan struktur bahan yang terdiri dari tiga elemen, yaitu mekanik (kekerasan, kekenyalan), geometrik (berpasir, beremah), dan mouthfeel (berminyak, berair) (Setyaningsih et al. 2010). Semakin banyak penggunaan beras merah maka tekstur bubur semakin keras. Hal ini sejalan dengan penelitian Forsalina (2016) bahwa penggunaan beras merah yang semakin banyak menghasilkan bakpao yang kurang empuk atau agak keras.

Tingkat kesukaan pada bubur bayi MP-ASI dipengaruhi oleh aspek penilaian yang lain. Penelitian mengenai beras merah oleh Ruslan (2015) menyimpulkan semakin banyak penambahan tepung beras 
merah maka nilai rata-rata kesukaan panelis semakin tinggi dan hasil uji hedonik menunjukkan semakin tinggi penambahan tepung beras merah maka nilai rata-rata tingkat kesukaan panelis semakin rendah.

Hasil uji organoleptik oleh bayi yang menggunakan skala raut muka menunjukkan bahwa bubur bayi dengan bahan dasar kacang tunggak dan beras merah belum bisa diterima bayi dengan baik. Hal ini ditunjukkan dengan nilai rata-rata dari skala raut muka yang ditunjukkan bayi serta sekitar $40 \%$ bayi masih melepeh atau memuntahkan bubur saat disuapi. Daya terima makanan bayi dipengaruhi oleh beberapa faktor diantaranya usia pertama kali dikenalkan MP-ASI, pengulangan pemberian suatu bahan makanan dan variasi makanan yang diberikan (Niklaus, 2011).

Kandungan protein pada buburbayi sudah sesuai dengan acuan SNI tentang bubur bayi SNI 01-7111.4-2005 yaitu 2-5,5 gr per 100 kkal. Namun kandungan kalsium pada kedua sampel masih kurang dari ketentuan SNI yaitu $\geq 80 \mathrm{mg}$.

\section{SIMPULAN dan SARAN}

\section{A. Simpulan}

1. Nilai rata-rata warna tertinggi pada $\mathrm{X} 1$, aroma tertinggi pada $\mathrm{X} 1$, rasa tertinggi pada X2,tekstur memiliki nilai yang sama, tingkat kesukaan tertinggi pada $\mathrm{X} 1$

2. Nilai rata-rata tertinggi pada uji penerimaan oleh bayi dan lebih sedikit adanya lepehan yaitu pada formula $\mathrm{X} 2$

3. Kandungan protein dan pada bubur paling tinggi yaitu pada X1.

4. Hasil analisis uji statistik menunjukkan bahwa penggunaan kacang tunggak dan beras merah berpengaruh terhadap warna dan rasa namun tidak berpengaruh pada aroma, tekstur dan tingkat kesukaan.

\section{B. Saran}

1. Penelitian dengan penggunaan bahan makanan kacang tunggak sebaiknya perlu pengolahan khusus untuk menghilangkan aroma dan rasa langu pada kacang.

2. Penelitian dengan penggunaan bahan makanan kacang tunggak dan beras merah sebaiknya di lakukan intervensi pada bayi stunting untuk melihat pengaruhnya terhadap status gizi.

\section{DAFTAR PUSTAKA}

Amalia Rizki Thoif. 2014. Formulasi Substitusi Tepung Beras Merah (Oryza Nivara) Dan Ketan Hitam (Oryza Sativa Glutinosa) Dalam Pembuatan Cookies Fungsional. Skripsi Departemen Gizi Masyarakat Fakultas Ekologi Manusia Institut Pertanian Bogor Bogor

Bernard-Bonnin, A. 2006. Feeding problems of infants and toddlers. Can Fam Physician.;52:1247-51 
Febriana, Ana.2014. Evaluasi Kualitas Gizi, Sifat Fungsional, dan Sifat Sensoris SalaLauak dengan Variasi Tepung Beras Sebagai Alternatif Makanan Sehat.JurnalTeknosains Pangan Vol 3 (2). Surakarta

Foley KM, Gelband H, editors. Improving Palliative Care for Cancer [monograph on the internet]. Washington: National Academy Press; 2001 [cited 2020 Feb 11]. Available at: http://www.nap.edu/books/0309074 029/html/.

Forsalina Fiensa Komang Ayu Nocianitri, I Desak Pt. Kartika Pratiwi .2016. Pengaruh Substitusi Terigu Dengan Tepung Beras Merah (Oryza Nivara) Terhadap Karakteristik Bakpao . Jurnal ITEPA UnudVol 5 No 2

Ilowefah, M, Chinmac., Bakar, J., Ghazali H., Muhammad, K., Makeri M. 2014. Brown rice Flour functional food ingredient. Internasional Journal Of Environmental Research and public Health. 3,149159 doi 10.3390/foods 3010149

Guinard J. 2001.Sensory and consumer testing with children. Trends Food Sci Technol Vol 11:273-283

Niklaus.S. Children's acceptance of new foods at weaning. Role of Practices of weaning and of food sensory properties. Appetite. Elsevier Ltd; 2011;57(3);812
Pengkumsri, N., C. Chaiyasut, C. Saenjum, S. Sirilun, S. Peerajan, P.Suwannalert, S. Sirisattha, B.S. Sivamaruthi. 2015. Physico-chemical and antioxidatve propreeties of black, brown and redrice varieties of North Thailand. Food Sci. Technol. Campinas,35(2): 331-338

Puspita Devillya Dewi, Agus Wijanarka, Nutya Febriana.2016. Pengaruh Variasi Pencampuran Tepung Beras Merah (Oryza Nivara) Dan Tepung Terigu Terhadap Sifat Fisik, Organoleptik Dan Kadar Antosianin Bolu Kukus. Jurnal Medika Respati Vol XI Nomor 3 Julil 2016 ISSN : 1907 - 3887

Rosida, Dedin, Qomariah Hardiyanti, Murtiningsih. 2013. Kajian Dampak Substitusi Kacang Tunggak Pada Kualitas Fisik Dan Kimia Tahu. Jurnal UPN Veteran. Program Studi Teknologi Pangan. FTI UPN Veteran : Jawa Timur.

Rukmana, R dan Yuniarsih, Y. 2001. Kedelai: Budidaya Dan Pasca Panen. Jakarta: Kanisius

Ruslan, M. (2015). Pengaruh penambahan tepung Beras merah (Oryza nivara) dan kurma (Phoenix dactylifera) terhadap Indeks Glikemik (IG) serta daya terima brownies (Skripsi yang tidak 
dipublikasikan). Universitas Airlangga, Surabaya.

Sarofa U, Mulyani T, Wibowo YA. 2013.

Pembuatan cookies berserat tinggi dengan memanfaatkan tepung ampas mangrove (Sonneratiacaseolaris) [skripsi]. Surabaya (ID): FTI UPN "Veteran"

Setyaningsih D, Apriyantono A, Sari MP. 2010. Analisis Sensori untuk Industri Pangan dan Agro. Bogor (ID): IPB Press

Riskesdas. 2013. Laporan Nasional Riset Kesehatan Dasar (Riskesdas Tahun 2013). Jakarta : Badan Penelitian dan Pengembangan Kesehatan Departemen Kesehatan RI

Umar Arif. 2014. 800 Balita Jatim Alami

Gizi Buruk. http://www.indonesia1.com. Diakses tanggal 10 Agustus 2019

Widodo R. 2015. Pemberian Makanan, Suplemen \& Obat pada Anak. Jakarta: Buku Kedokteran EGC 